\title{
Soil Moisture Profile Analysis Using Tensiometer under Different Discharge Rates of Drip Emitter
}

\author{
Shashi Shekhar ${ }^{1}$, Manish Kumar ${ }^{2 *}$ Anuradha Kumari ${ }^{2}$ and S.K. Jain ${ }^{1}$ \\ ${ }^{1}$ Dr. R.P.C.A.U., Pusa, Samastipur, Bihar, India \\ ${ }^{2}$ G. B. Pant University of Agriculture and Technology, Pantnagar, Uttrakhand, 263153, India \\ *Corresponding author
}

\section{A B S T R A C T}

\begin{tabular}{|l|}
\hline Ke y w o r d s \\
Drip irrigation system, \\
Moisture profile, \\
Tensiometer, \\
Horizontal spreading \\
and Vertical \\
spreading.
\end{tabular}

Being one of the key factor in designing and managing the drip irrigation system, moisture profile is essential for optimization of spacing of emitters as well as laterals. The experiments include surface drip irrigation system having three discharges viz., 2 lph, 4.4 lph and $6 \mathrm{lph}$ conducted in farms of pump and Wells laboratory shed of College of Agricultural Engineering, Samastipur, Bihar. The experiment was managed in a metallic cylindrical tank having suitable dimensions which was full of soil. The experiments were conducted by drip emitters of different discharge rates and the tenacity of moisture in soil for different discharge was measures with tensiometer. Contour maps were plotted from the data recorded during the experiment for different discharge rates of $2 \mathrm{lph}, 4.4 \mathrm{lph}$ and 6 lph using the Surfer -7 software. The experiment concluded that the horizontal spread of water increases with increase in discharge of emitter. The horizontal spread was observed to be about $23.3 \%$ and $43.3 \%$ more when the emitter discharge rate increased from 2 lph to $4.4 \mathrm{lph}$ and $6.0 \mathrm{lph}$ respectively. The vertical spread of water decreases with increase in emitter discharge rate. The vertical spread was observed to be about $18.0 \%$ and $32.0 \%$ less when discharge was increased from 2 lph to $4.4 \mathrm{lph}$ and $6.0 \mathrm{lph}$ respectively.

\section{Introduction}

The adoption of tensiometer has increase since last decades for the measurement of tenacity of moisture due to ease in measurement and also their accuracy. It works on the principle that a partial vacuum is created in a closed chamber when water moves out through a porous ceramic cup to the surrounding soil. Tension is measured by a manometer or a vacuum gauge which may be graduated in either hundredths of an atmosphere or in centimeters of water. In other words, tensiometer measures the surface tension of a liquid or the interfacial tension between two immiscible liquids.
Surface tension involves an important parameter in characterizing a liquids ability to wet a solid surface and to understand adhesion. So, tensiometer helps in soil moisture profile measurement. Acar et al., (2008) studied the effect of different applied water by use of different emitter discharges on the wetting patterns of a loam or clay-loam soil under trickle source.

Therefore, tensiometers are used in irrigation scheduling to help farmers and other irrigation managers to determine when to water. In conjunction with a water retention 
curve, tensiometers can be used to determine how much to water.

The relentless increase in population and the resulting spurt in the demand for water require careful planning and management of the limited water resources. According to Census of India, 2011, the decadal growth rate of population of India is $17.64 \%$. It is essential that food production should increase to feed the growing population. More is the demand for food more will be the requirement of water to irrigate the field. Though, the water resource is limited and it has to be optimally harnessed and beneficially utilized with appropriate priorities of use. To achieve water security and food security it is necessary to increase the water use efficiency and water productivity, producing more with less water in all water sectorial uses particularly the agriculture sector is a big challenge. To improve water and nutrient use efficiency, growers need to maintain the soil water in the crop root zone at optimal levels for plant growth and minimal nutrient leaching.

Technically, several approaches are now implemented for better water saving in the irrigated agriculture among them the introduction of the new irrigation techniques such as surface and subsurface drip irrigation, sprinkler irrigation and pivot systems. Singhet al., (2005) found that the information on depths and widths of wetted zone of soil under subsurface application of water plays the great significance in design and management of subsurface drip irrigation (SDI) system for delivering required amount of water and chemical to the plant.

The drip irrigation system offers key advantages for meeting contemporary water and nutrient management efficiency standards, since it allows for accurate control of water supplied in small quantities directly to the root zone (forming partially wetted soil volume). Frequent irrigation helps maintaining favorable water conditions (near field capacity) for root proliferation within the partially wetted soil volume. Moreover, matching application rates with plant uptake through the intensely proliferated wetted volume ensures efficient water and nutrient uptake while reducing deep percolation losses of water and agrochemicals. Assouline (2002) studied the drip irrigation at a rate close to plant water uptake necessitates low application rates (microdrip), which affect soil water regime and plant response. Patel \& Rajput (2008) reported that Sub-surface drip irrigation provides water to the plants around the root zone while maintaining a dry soil surface. A problem associated with the subsurface drip irrigation is the formation of cavity at the soil surface above the water emission points. This can be resolved through matching dripper flow rates to the soil hydraulic properties. Badr \& Abuarab (2011) studied the soil moisture status under surface and subsurface drip irrigation systems, as a function of the variation in the distance between drippers along and between laterals.

Moisture measurements were carried out using neutron moisture meter technique, and water distribution uniformity was assessed by applying Surfer Model. Researcher may go for further details and studied some more reviews of Al-Ghobari et al., (2012), Dough et al., (2013), Elmaloglou and Diamantopoulos (2009), Li et al., (2004), Kandelous et al., (2010), Siyal and Skaggs (2009), Subbaiah and Mashru (2013), Wang et al., (2005), Zhenhua et al., (2002), Buttaro et al., (2015), Vorobev and Boghi (2016), Dabach et al., (2016) etc.

In present study, the main objective is to evaluate the effects of discharge rate on moisture profile in the soil which is measured by the use of tensiometer. 


\section{Materials and Methods}

\section{Location of experimental site}

The experimental site is located in the experimental farm of Pumps and Wells laboratory shed of College of Agricultural Engineering. The experimental site is located in Samastipur district of N. Bihar. It lies at $25.980 \mathrm{~N}$ latitude, $85.670 \mathrm{~S}$ longitudes and at altitude of about $52.92 \mathrm{~m}$ above the sea level. Climate is sub- humid- west monsoon. The annual rainfall in the area is about $1270 \mathrm{~mm}$, out of which $1026 \mathrm{~mm}(80.78 \%)$ is received during monsoon months (July- September) and rest during other seasons of the year. The average minimum and maximum temperatures during the hottest months of May to June goes up to $3^{0}-4^{0} \mathrm{C}$ and $43^{0}-44$ ${ }^{0} \mathrm{C}$ respectively.

\section{Description of the materials used in the experiment}

\section{Metallic cylindrical tank}

A Metallic cylindrical tank of diameter $1 \mathrm{~m}$ and height $1 \mathrm{~m}$ was used to conduct the experiment. The tank was filled with the soil and was given due compaction to bring it to the natural state. Holes were made at the bottom of the cylinder to drain excess water.

\section{Tensiometer}

It is an instrument which measures the tenacity of moisture being held with the soil i.e. energy needed by a plant to extract the moisture from the soil. It consists of ceramic cup. When the ceramic comes in contact with a dry soil, water flows out of the tensiometer leaving a vacuum behind it. This vacuum equals to the soil suction, which is then measured and read in gauge attached to the tensiometer. If the soil is irrigated the soil suction reduces and water flows back into the tensiometer to reduce the vacuum so that it again equals the soil suction. Tensiometers with different lengths of cylindrical tubes viz. $30 \mathrm{~cm}, 60 \mathrm{~cm}, 100 \mathrm{~cm}$ and $150 \mathrm{~cm}$ were used to take observation of soil moisture tension at different depths.

\section{Methodology adopted for the experiment}

\section{Determination of soil texture}

Soil texture was determined by hydrometer method. The soil used in this experiment is Sandy Clay Loam. The contribution of the sand, silt and clay are 52\%, 18\% and $30 \%$ respectively.

\section{Determination of bulk density}

Bulk density of soil was determined using core sampler $($ Height $=18 \mathrm{~cm}$, Diameter $=7.5$ $\mathrm{cm}$ ) of known volume. The cylinder of core sampler which has cutting edge was driven into the soil and an undisturbed sample of soil was obtained within the core sampler. The samples were carefully trimmed off at both ends of core sampler. The samples were then dried in an oven at 105 for about 24 hours until all the moisture was driven off and the samples were weighted. The volume of core sampler (inside) is same as volume of soil in core. Then, the bulk density is calculated by using the formula given below.

Bulk Density $=\frac{\text { mass of oven dry soil sample }(\mathrm{g})}{\text { total volume of core cutter }(\mathrm{cm} 3)}$

\section{Installation of tensiometer}

The tensiometer was filled with clean water. The rubber stopper was pressed into the cylindrical tube and was sealed with Vaseline. Then, the tensiometers were left in vertical position for 20 - 30 minutes so that ceramic cup gets fully saturated. The holes were dug out at the desired points upto desired depths and tensiometers were placed vertically in it. The holes were filled with finer particles of 
soil so that there is no more pocket of air around the tensiometer. After about half an hour when the tensiometers reached in equilibrium condition, the set up was considered to be ready for the experimentation.

\section{Calibration of tensiometer}

For the calibration purpose 5 tensiometers were used. The site was levelled first and then tensiometers were installed in it. Water was applied uniformly over it. After half an hour, the tensiometer starts showing deflection in readings. The readings of tensiometers and its corresponding reading of soil moisture in digital moisture meter was noted. Such observations were recorded for wide range of soil moisture. A graph was plotted between moisture meter readings and tensiometers readings to establish a relationship between the two parameters.

\section{Installation of set up for the experiment}

The soil was filled in the tank upto $90 \mathrm{~cm}$ height leaving $10 \mathrm{~cm}$ at top empty. The soil was compacted gently in layers. The soil was allowed to settle down. The tensiometers were installed in the cylindrical tank. The emitter was installed at the center and the tensiometers were installed at the radial distances of $15 \mathrm{~cm}, 30 \mathrm{~cm}, 45 \mathrm{~cm}, 60 \mathrm{~cm}$, and $90 \mathrm{~cm}$. The emitter was connected to overhead tank through the pipe with valve fitted on it to regulate the discharge. Discharge rates of $2 \mathrm{lph}, 4.4 \mathrm{lph}$ and $6 \mathrm{lph}$ were used for the experiment. Readings were noted down at regular interval of $15 \mathrm{~min}$ for 6 lph discharge rate and $30 \mathrm{~min}$ for $4.4 \mathrm{lph}$ and 2 lph discharge rates.

\section{Plotting of contour maps}

Contour maps were plotted from the data recorded during the experiment for different discharge rates of $2 \mathrm{lph}, 4.4 \mathrm{lph}$ and $6 \mathrm{lph}$ using the Surfer -7 software.

\section{Results and Discussion}

\section{Bulk density}

The bulk density of soil sample taken for discharge $2 \mathrm{lph}, 4.4 \mathrm{lph}$, and $6 \mathrm{lph}$ was obtained 1.46, 1.47 and $1.41 \mathrm{~g} / \mathrm{cm}^{3}$ respectively.

\section{Calibration of the tensiometer}

The tensiometers were calibrated using the digital soil moisture meter. The tensiometers were installed at the ground surface and different moisture levels were maintained. The moisture content reading of the digital soil moisture meter and corresponding values of soil moisture tension in tensiometers was noted. Reading of the tensiometer and its corresponding values of moisture content is given in table 1 . From this table, a graph was plotted keeping soil moisture tension (cbar) as $\mathrm{X}-$ axis and moisture content $(\%)$ as $\mathrm{Y}-$ axis. This calibration curve is shown in figure 1. From this curve, a relationship representing the best fit between the two parameters was established and is represented as

$Y=28.666 e^{-0.013 X} \ldots(3.1)$

$\left(\mathrm{R}^{2}=0.9838\right)$

Where, $\mathrm{Y}=$ soil moisture content $(\%), \mathrm{X}=$ soil moisture tension (cbar)

This equation was used for finding the soil moisture content corresponding to the soil moisture tension.

From figure 1, it is clear that as soil moisture tension increases the soil moisture content decreases. For example, moisture content for 6 cbar soil moisture tension is $27.4 \%$ whereas 
for 15 cbar soil moisture tension, moisture content is $23.5 \%$. Rate of decrease in moisture content decreases as soil moisture tension approaches to 0 and 100 cbar.

\section{Study of soil moisture profile}

\section{Soil moisture profile at 2 lph emitter discharge}

The contour map (Figure 2) shows the radial and vertical distance of iso-moisture lines of different moisture contents. In case of isomoisture lines (contour lines) having moisture content $17 \%$, the radial distance is $36.5 \mathrm{~cm}$ and for iso-moisture lines having moisture content $18 \%$, the radial distance is $30 \mathrm{~cm}$. In both case of iso-moisture lines $(18 \%$ and $17 \%)$, the vertical distance from the centre is beyond $90 \mathrm{~cm}$.

The maximum radial distance of iso-moisture lines from centre having moisture content $19 \%, 20 \%, 21 \%, 22 \%, 23 \%, 24 \%, 25 \%, 26 \%$, $27 \%$ and $28 \%$ are $25.5 \mathrm{~cm}, 22 \mathrm{~cm}, 18 \mathrm{~cm}, 14$ $\mathrm{cm}, 10 \mathrm{~cm}, 6 \mathrm{~cm}, 4 \mathrm{~cm}, 2.5 \mathrm{~cm}, 1.5 \mathrm{~cm}$ and
$0.5 \mathrm{~cm}$ respectively. This clearly shows that with increase in distance from the centre, the moisture content decreases.

Vertical distance of iso-moisture lines from the centre having moisture content $19 \%, 20 \%$, $21 \%, 22 \%, 23 \%, 24 \%, 25 \%, 26 \%, 27 \%$ and $28 \%$ are $89 \mathrm{~cm}, 66.5 \mathrm{~cm}, 53 \mathrm{~cm}, 40 \mathrm{~cm}, 27.5$ $\mathrm{cm}, 15 \mathrm{~cm}, 7.5 \mathrm{~cm}, 4 \mathrm{~cm}, 2 \mathrm{~cm}$ and $0.5 \mathrm{~cm}$ respectively. This clearly shows that as the distance from the centre increases vertically there is a decrease in moisture content i.e. with increase in distance from the centre there is a decrease in moisture content.

By observing the spacing between two consecutive iso-moisture lines both vertically and radially it can be concluded that isomoisture lines are clustered more densely in lateral direction as compared to vertical direction. In other words, it can be said that changes in moisture content is steeper radially than vertically. Thus, it is evident that vertical movement of water is predominant as compared to lateral movement.

Fig.1 Graph showing relationship between soil moisture content (\%) and soil moisture tension

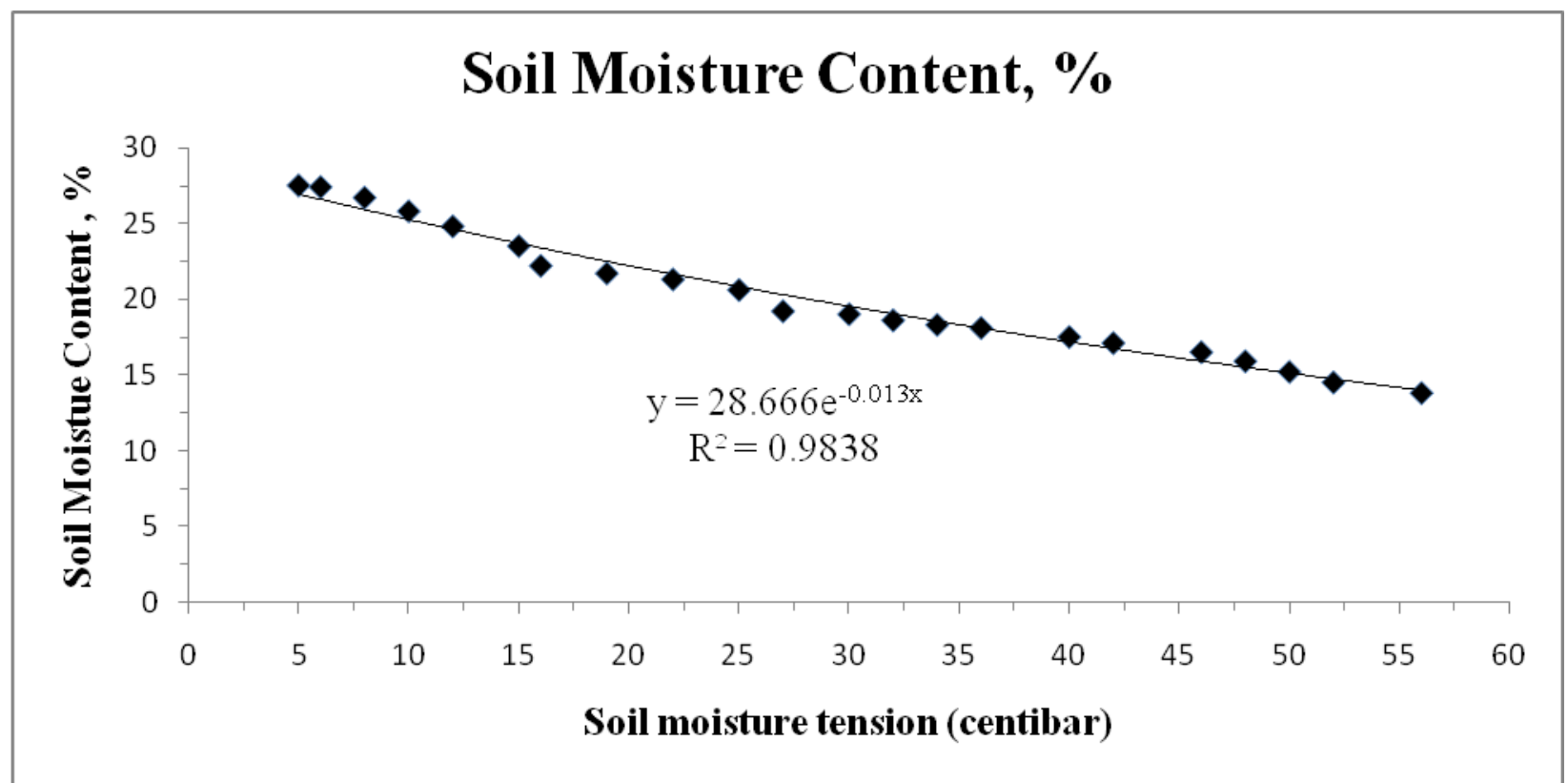


Fig.2 Soil moisture profile for 2 lph discharge rate

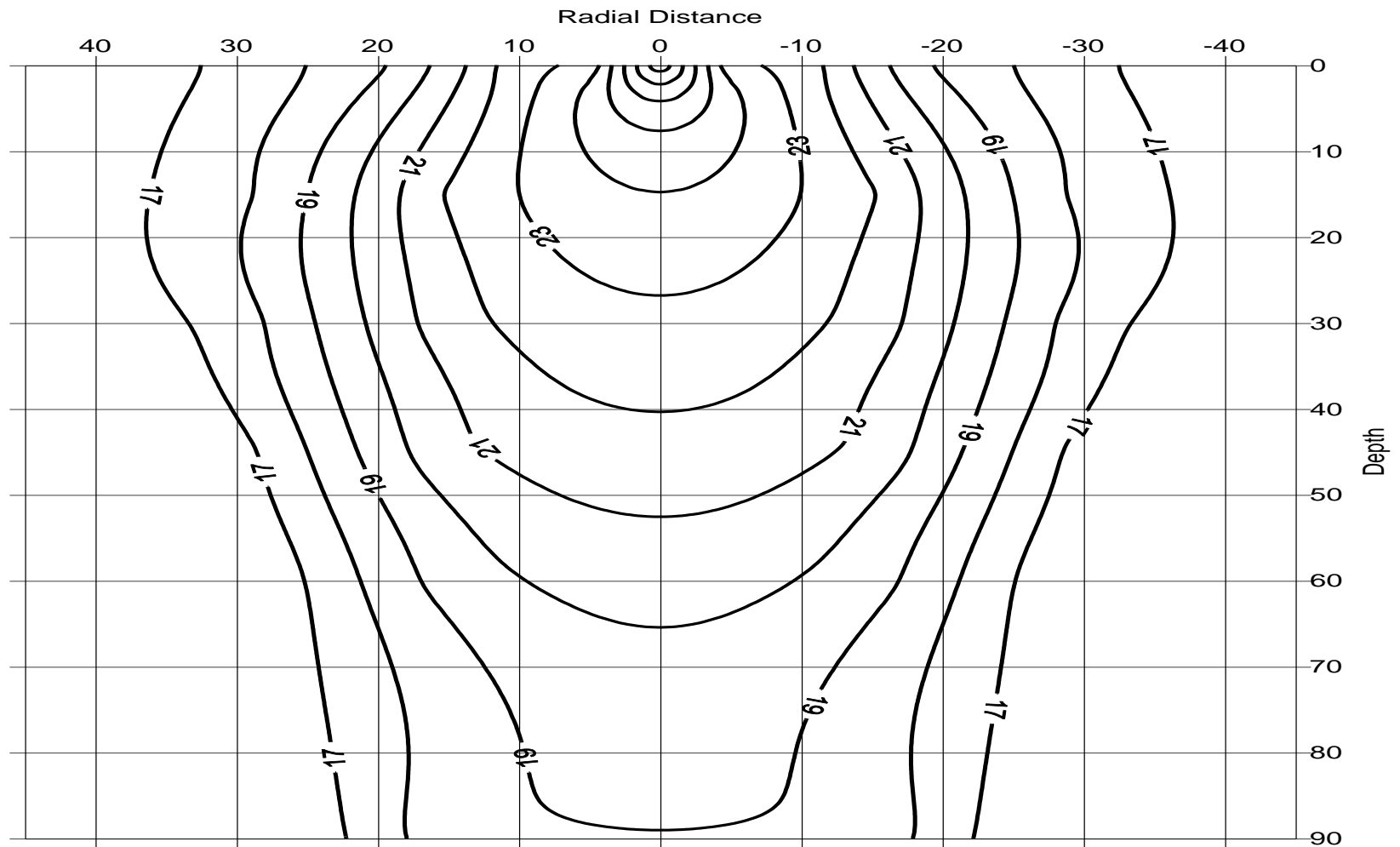

Fig.3 Soil moisture profile for 4.4 lph discharge rate

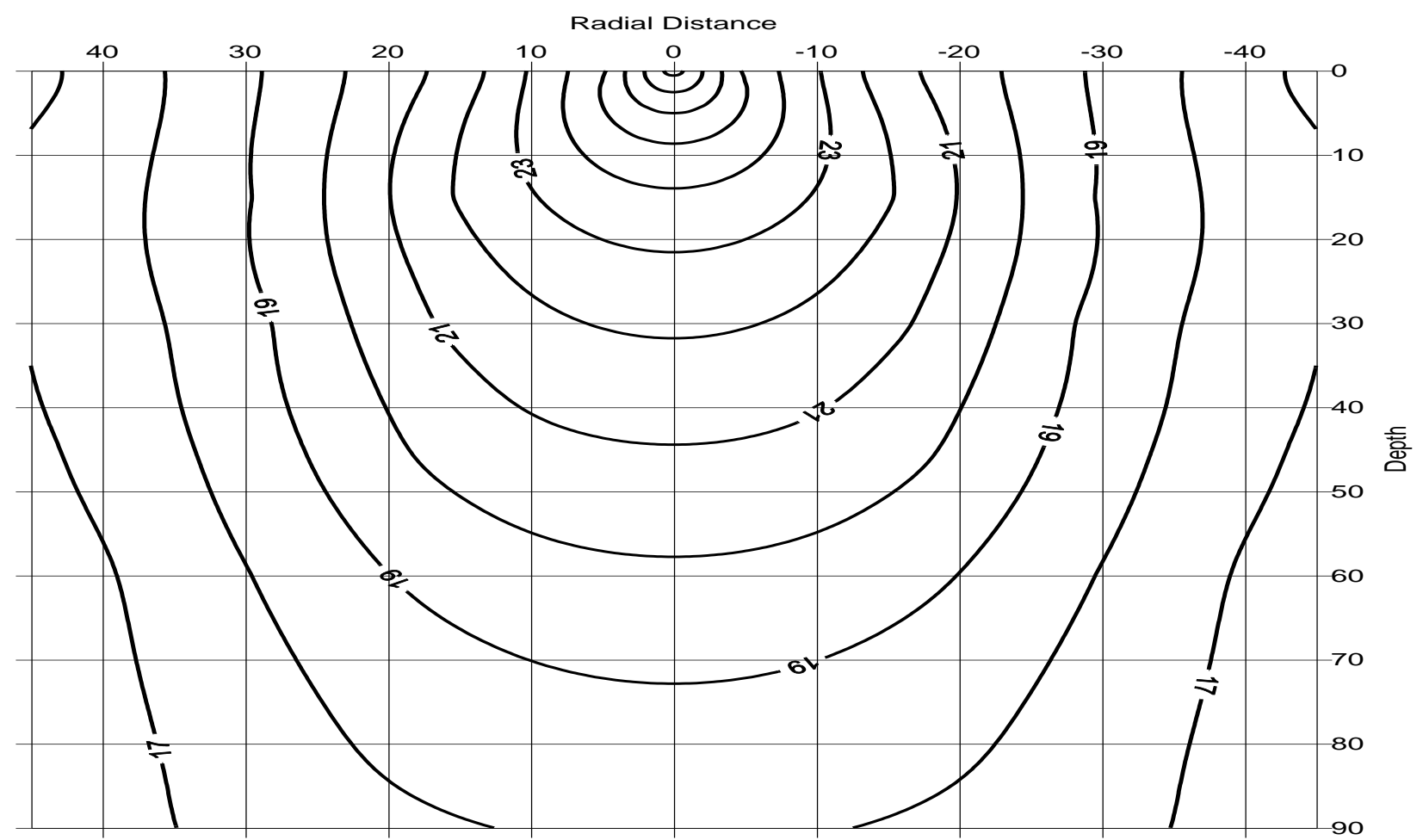


Fig.4 Soil moisture profile for 6 lph discharge rate

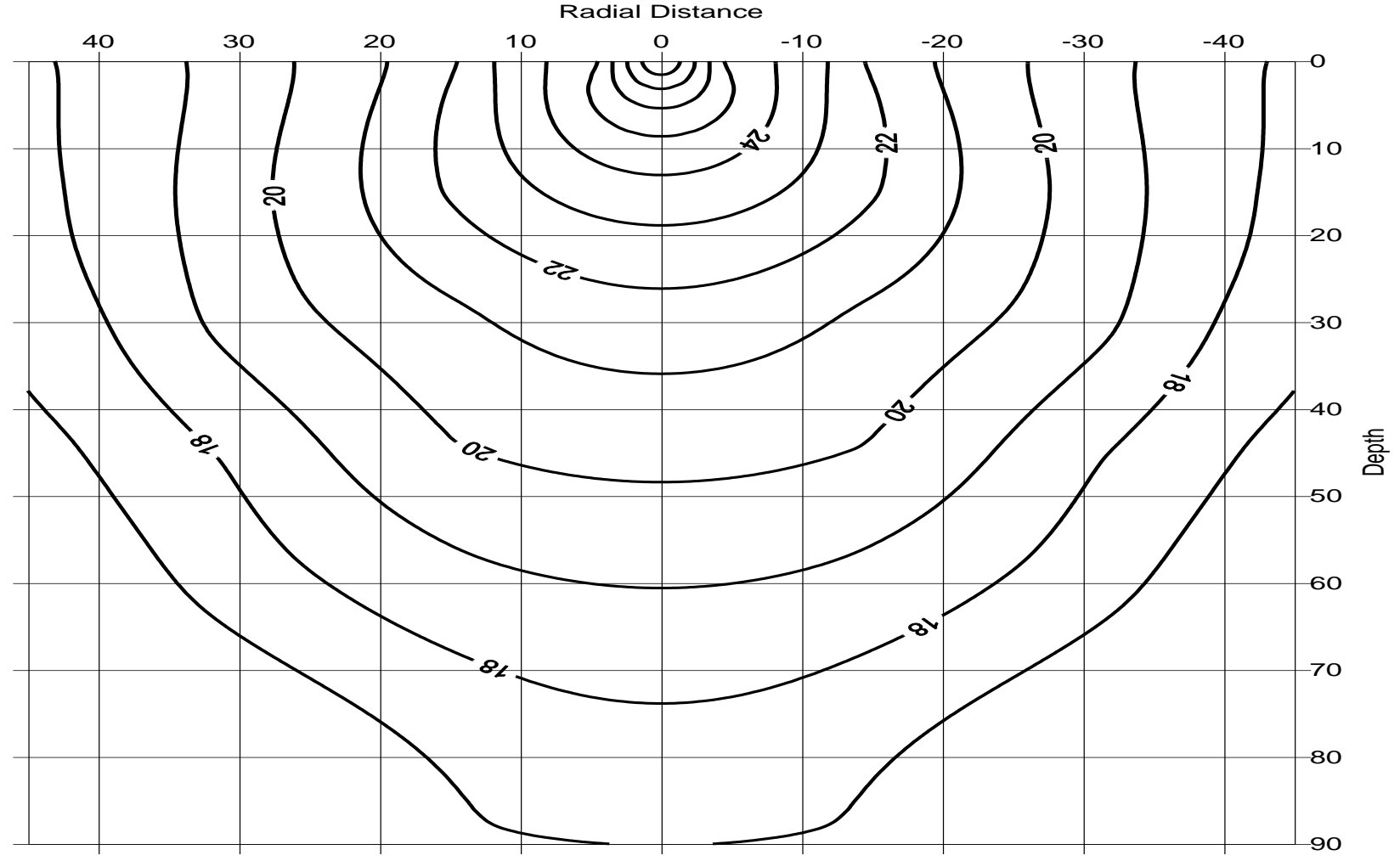

Table.1 Soil moisture content corresponding to soil moisture tension

\begin{tabular}{|c|c|c|c|}
\hline $\begin{array}{c}\text { Soil Moisture } \\
\text { Tension (Centibar) }\end{array}$ & $\begin{array}{c}\text { Soil Moisture } \\
\text { Content, } \%\end{array}$ & $\begin{array}{c}\text { Soil Moisture } \\
\text { Tension (Centibar) }\end{array}$ & $\begin{array}{c}\text { Soil Moisture } \\
\text { Content, } \%\end{array}$ \\
\hline 5 & 27.5 & 19 & 21.7 \\
\hline 6 & 27.4 & 22 & 21.3 \\
\hline 8 & 26.7 & 25 & 20.6 \\
\hline 10 & 25.8 & 27 & 19.2 \\
\hline 12 & 24.8 & 30 & 19 \\
\hline 15 & 23.5 & 32 & 18.6 \\
\hline 16 & 22.2 & 34 & 15.9 \\
\hline 36 & 18.1 & 48 & 15.2 \\
\hline 40 & 17.5 & 50 & 14.5 \\
\hline 42 & 17.1 & 52 & 13.8 \\
\hline 46 & 16.5 & 56 & \\
\hline
\end{tabular}

Soil moisture profile at $4.4 \mathrm{lph}$ emitter discharge rate

Figure 3 shows the contour map of moisture content at 4.4 lph discharge. Radial distance of iso-moisture lines having moisture content
$17 \%, 18 \%, 19 \%, 20 \%, 21 \%, 22 \%, 23 \%, 24 \%$, $25 \%, 26 \%, 27 \%$ and $28 \%$ are $>90 \mathrm{~cm}, 37 \mathrm{~cm}$, $30 \mathrm{~cm}, 24.5 \mathrm{~cm}, 20 \mathrm{~cm}, 15.5 \mathrm{~cm}, 11 \mathrm{~cm}, 7.5$ $\mathrm{cm}, 5 \mathrm{~cm}, 3.5 \mathrm{~cm}, 2 \mathrm{~cm}$ and $0.5 \mathrm{~cm}$ respectively as shown in figure 3 . Thus, it clearly indicates that greater is the distance 
from the centre lesser is the moisture content. Figure 3 shows the vertical distance of isomoisture lines having moisture content $17 \%$, $18 \%, 19 \%, 20 \%, 21 \%, 22 \%, 23 \%, 24 \%, 25 \%$, $26 \%, 27 \%$ and $28 \%$ are $>90,>90 \mathrm{~cm}, 73 \mathrm{~cm}$, $58 \mathrm{~cm}, 44.5 \mathrm{~cm}, 32 \mathrm{~cm}, 21.5 \mathrm{~cm}, 14 \mathrm{~cm}, 8 \mathrm{~cm}$, $5 \mathrm{~cm}, 2.5 \mathrm{~cm}$ and $0.5 \mathrm{~cm}$ respectively. Thus, it can be said that more is the distance in vertical direction lesser is the moisture content at that point.

\section{Soil moisture profile at 6 lph emitter discharge rate}

Figure 4 shows the contour map plotted for 6 lph discharge rate. From figure 4 it can be seen that radial distance of iso-moisture lines from the centre having the moisture content $17 \%, 18 \%, 19 \%, 20 \%, 21 \%, 22 \%, 23 \%, 24 \%$, $25 \%, 26 \%, 27 \%$ and $28 \%$ are $>45 \mathrm{~cm}, 43 \mathrm{~cm}$, $34.5 \mathrm{~cm}, 28 \mathrm{~cm}, 21.5 \mathrm{~cm}, 16.5 \mathrm{~cm}, 12 \mathrm{~cm}, 8$ $\mathrm{cm}, 5 \mathrm{~cm}, 3.5 \mathrm{~cm}, 2.5 \mathrm{~cm}$ and $1.5 \mathrm{~cm}$ respectively as shown in figure 4 . This clearly shows that with increase in distance from the centre, the moisture content decreases.

As shown in figure 4, the vertical distance of iso-moisture lines from the centre having moisture content 17\%, 18\%, 19\%, 20\%, 21\%, $22 \%, 23 \%, 24 \%, 25 \%, 26 \%, 27 \%$ and $28 \%$ are $90 \mathrm{~cm}, 74 \mathrm{~cm}, 60.5 \mathrm{~cm}, 48 \mathrm{~cm}, 36 \mathrm{~cm}, 26$ $\mathrm{cm}, 19 \mathrm{~cm}, 13 \mathrm{~cm}, 8 \mathrm{~cm}, 5 \mathrm{~cm}, 3 \mathrm{~cm}$ and 1.5 $\mathrm{cm}$ respectively. This vertical distance from the centre shows that with increase in distance the moisture content decreases.

\section{Comparison of soil moisture profile at different discharge rates of emitter}

At discharge rate of $2 \mathrm{lph}, 4.4 \mathrm{lph}, 6 \mathrm{lph}$, the radial distance of iso-moisture lines from the centre having moisture content $17 \%, 18 \%$, $19 \%, 20 \%, 21 \%, 22 \%, 23 \%, 24 \%, 25 \%, 26 \%$, $27 \%$ and $28 \%$ was found to be $36.5 \mathrm{~cm},>45$ $\mathrm{cm}$ and $>45 \mathrm{~cm} ; 30 \mathrm{~cm}, 37 \mathrm{~cm}$ and $43 \mathrm{~cm}$; $25.5 \mathrm{~cm}, 30 \mathrm{~cm}$ and $34.5 \mathrm{~cm} ; 22 \mathrm{~cm}, 24.5 \mathrm{~cm}$ and $28 \mathrm{~cm} ; 18 \mathrm{~cm}, 20 \mathrm{~cm}$ and $21.5 \mathrm{~cm} ; 14 \mathrm{~cm}$, $15.5 \mathrm{~cm}$ and $16.5 \mathrm{~cm} ; 10 \mathrm{~cm}, 11 \mathrm{~cm}$ and 12 $\mathrm{cm} ; 6.5 \mathrm{~cm}, 7.5 \mathrm{~cm}$ and $8 \mathrm{~cm} ; 4 \mathrm{~cm}, 5 \mathrm{~cm}$ and $5 \mathrm{~cm} ; 2.5 \mathrm{~cm}, 3.5 \mathrm{~cm}$ and $3.5 \mathrm{~cm} ; 1.5 \mathrm{~cm}, 2$ $\mathrm{cm}$ and $2.5 \mathrm{~cm} ; 0.5 \mathrm{~cm}, 0.5 \mathrm{~cm}$ and $1.5 \mathrm{~cm}$ respectively. This clearly shows that for the same moisture content, the radial distance of iso-moisture lines from the centre is greatest for $6 \mathrm{lph}$ followed by $4.4 \mathrm{lph}$ and last is $2 \mathrm{lph}$ discharge. Thus, it can be said that more is the discharge rate more is the lateral movement of water.

At discharge rate of $2 \mathrm{lph}, 4.4 \mathrm{lph}, 6 \mathrm{lph}$, the vertical distance of iso-moisture lines from the centre having moisture content $17 \%, 18 \%$, $19 \%, 20 \%, 21 \%, 22 \%, 23 \%, 24 \%, 25 \%, 26 \%$, $27 \%$ and $28 \%$ was found to be $>90 \mathrm{~cm},>90$ $\mathrm{cm}, 90 \mathrm{~cm} ;>90 \mathrm{~cm},>90 \mathrm{~cm}$ and $74 \mathrm{~cm} ; 89$ $\mathrm{cm}, 73 \mathrm{~cm}$ and $60.5 \mathrm{~cm} ; 66.5 \mathrm{~cm}, 58 \mathrm{~cm}$ and $48 \mathrm{~cm} ; 53 \mathrm{~cm}, 44.5 \mathrm{~cm}$ and $36 \mathrm{~cm} ; 40 \mathrm{~cm}, 32$ $\mathrm{cm}$ and $26 \mathrm{~cm} ; 27.5 \mathrm{~cm}, 21.5 \mathrm{~cm}$ and $19 \mathrm{~cm}$; $15 \mathrm{~cm}, 14 \mathrm{~cm}$ and $13 \mathrm{~cm} ; 7.5 \mathrm{~cm}, 8 \mathrm{~cm}$ and 8 $\mathrm{cm} ; 4 \mathrm{~cm}, 5 \mathrm{~cm}$ and $5 \mathrm{~cm} ; 2 \mathrm{~cm}, 2.5 \mathrm{~cm}$ and 3 $\mathrm{cm} ; 0.5 \mathrm{~cm}, 0.5 \mathrm{~cm}$ and $1.5 \mathrm{~cm}$ respectively.

This clearly shows that for the same moisture content, the vertical distance of iso-moisture lines from the centre is greatest for $2 \mathrm{lph}$ followed by $4.4 \mathrm{lph}$ and last is $6 \mathrm{lph}$ discharge. Thus, it can be said that lower is the discharge rate greater is the vertical movement of water.

The wetting pattern of drip irrigation is very interesting and of utmost importance as it plays a vital role in the growth of crops in the field. Drip irrigation must be designed so that its discharge nearly approaches plants daily consumptive use of water an also its wetting profile suits the root system of the plants. Tensiometer has been preferred because it is easy to use and is low cost instruments compared to other moisture measuring instrument to measure the soil moisture.

Based on the analysis of all the three contour 
maps drawn from observed data it is concluded that the horizontal spread of water increases with increase in discharge of emitter. The horizontal spread was observed to be about $25.4 \%$ and $47.8 \%$ more when the emitter discharge rate increased from 2 lph to $4.4 \mathrm{lph}$ and $6.0 \mathrm{lph}$ respectively. While the vertical spread of water decreases with increase in emitter discharge rate. The vertical spread was observed to be about $18.0 \%$ and $32.0 \%$ less when discharge was increased from $2 \mathrm{lph}$ to $4.4 \mathrm{lph}$ and $6.0 \mathrm{lph}$ respectively.

Based on the soil moisture recorded at different points below the discharging emitter under different discharge rates it can be concluded that the spread of water increases in horizontal direction and decreases in vertical direction when the emitter discharge is increased. Hence, the crops which have deeper root system must be irrigated with smaller discharge rates compared to crops which have shallow roots.

\section{References}

Acar, B., Topak, R. and Mikailsoy, F., 2009. Effect of applied water and discharge rate on wetted soil volume in loam or clay-loam soil from an irrigated trickle source. African Journal of Agricultural Research, 4(1), pp.049-054.

Al-Ghobari, H.M. and El Marazky, M.S.A., 2012. Surface and subsurface irrigation systems wetting patterns as affected by irrigation scheduling techniques in an arid region. African Journal of Agricultural Research, 7(44), pp.59625976.

Assouline, S., 2002. The effects of microdrip and conventional drip irrigation on water distribution and uptake. Soil Science Society of America Journal, 66(5), pp.1630-1636.

Badr, A.E. and Abuarab, M.E., 2013. Soil moisture distribution patterns under surface and subsurface drip irrigation systems in sandy soil using neutron scattering technique. Irrigation science, 31(3), pp. 317-332.

Buttaro, D., Santamaria, P., Signore, A., Cantore, V., Boari, F., Montesano, F.F. and Parente, A., 2015. Irrigation management of greenhouse tomato and cucumber using tensiometer: effects on yield, quality and water use. Agriculture and Agricultural Science Procedia, 4, pp.440-444.

Dabach, S., Shani, U. and Lazarovitch, N., 2016. The influence of water uptake on matric head variability in a dripirrigated root zone. Soil and Tillage Research, 155, pp.216-224.

Douh, B., Boujelben, A., Khila, S. and Mguidiche, A.B.H., 2013. Effect of subsurface drip irrigation system depth on soil water content distribution at different depths and different times after irrigation. LARHYSS Journal ISSN 1112-3680, (13).

Elmaloglou, S. and Diamantopoulos, E., 2009. Simulation of soil water dynamics under subsurface drip irrigation from line sources. Agricultural Water Management, 96(11), pp.1587-1595.

Kandelous, M.M. and Šimůnek, J., 2010. Numerical simulations of water movement in a subsurface drip irrigation system under field and laboratory conditions using HYDRUS2D. Agricultural Water Management, 97(7), pp.1070-1076.

Li, J., Zhang, J. and Rao, M., 2004. Wetting patterns and nitrogen distributions as affected by fertigation strategies from a surface point source. Agricultural Water Management, 67(2), pp.89-104.

Naglic, B., 2011. Modelling and analysis of soil wetting patterns under surfrace drip irrigation.

Patel, N. and Rajput, T.B.S., 2008. Dynamics and modeling of soil water under 
subsurface drip irrigated onion. Agricultural water management, 95(12), pp.1335-1349.

Singh, D.K., Rajput, T.B.S., Sikarwar, H.S., Sahoo, R.N. and Ahmad, T., 2006. Simulation of soil wetting pattern with subsurface drip irrigation from line source. Agricultural Water Management, 83(1), pp.130-134.

Siyal, A.A. and Skaggs, T.H., 2009. Measured and simulated soil wetting patterns under porous clay pipe subsurface irrigation. Agricultural water management, 96(6), pp.893-904.

Subbauah, R. and Mashru, H.H., 2013. Modeling for predicting soil wetting radius under point source surface trickle irrigation. Agricultural Engineering
International: CIGR Journal, 15(3), pp.1-10.

Vorobev, A. and Boghi, A., 2016. Phase-field modelling of a miscible system in spinning droplet tensiometer. Journal of colloid and interface science, 482, pp.193-204.

Wang, F.X., Kang, Y. and Liu, S.P., 2006. Effects of drip irrigation frequency on soil wetting pattern and potato growth in North China Plain. Agricultural Water Management, 79(3), pp.248-264.

Zhenhua, Z., Huanjie, C., Yongchang, G. and Baojiang, G., 2002. Experimental Study on Factors Effecting Soil Wetted Volume of Clay Loam Under Drip Irrigation [J]. Transactions of The Chinese Society of Agricultural Engineering, 2, p.004.

\section{How to cite this article:}

Shashi Shekhar, Manish Kumar, Anuradha Kumari and Jain, S.K. 2017. Soil Moisture Profile Analysis Using Tensiometer under Different Discharge Rates of Drip Emitter. Int.J.Curr.Microbiol.App.Sci. 6(11): 908-917. doi: https://doi.org/10.20546/ijcmas.2017.611.106 